\title{
EDITORIAIS
}

\section{O FINANCIAMENTO DA PESQUISA EM DOENÇAS TROPICAIS NO BRASIL}

As primeiras manifestações de apoio oficial à pesquisa médica no Brasil ocorreram em fins do século passado, quando inumeras doenças infecto-contagiosas assolavam a região sudeste do pais, com sérios prejuizos para a economia e a administração da jovem república. Foram então criados, em São Paulo, o Instituto Butantan e o Instituto Bacteriológico, mais tarde transformado em Instituto Adolfo Lutz e, no Rio de Janeiro, o Instituto Soroterápico de Manguinhos, mais tarde denominado Instituto Oswaldo Cruz em homenagem ao seu notável fundador.

Esses Institutos não apenas cumpriram o papel para o qual haviam sido criados, de dar suporte às atividades de controle das epidemias de febre amarela, de variola e de peste bubônica, como também, particularmente no caso de Manguinhos, projetaram o nome do Brasil no cenário científico internacional.

A partir da segunda década deste século, com a morte ou aposentadoria dos seus principais lideres, os citados institutos começaram a encontrar dificuldades em obter o apoio do governo para dar continuidade às suas pesquisas, as quais acabaram sendo suplantadas pelas atividades de rotina.

Após a criação da Universidade do Brasil, no Rio de Janeiro, em 1922, e em particular depois da fundação da Universidade de São Paulo em 1934, além da criação de novas Faculdades de Medicina em diversas capitais do país, inicia-se uma nova fase de pesquisa em doenças infecciosas e parasitárias no âmbito dos Hospitais de Clinicas e dos laboratórios das cadeiras básicas. Essa não era todavia uma atividade sistemática: era antes um esforço isolado de cientistas que lutavam com grandes dificuldades e dependiam freqüentemente do financiamento das Fundações estrangeiras.

Foi somente no início da década dos cinqüenta que começou o apoio do Governo brasileiro à pesquisa, marcado pela criação do Conselho Nacional de Pesquisas - CNPq e da Campanha de Aperfeiçoamento do Pessoal de Ensino Superior - CAPES. Passavam assim os pesquisadores brasileiros a contar com agências financiadoras do governo voltadas para a concessão de auxílios para a pesquisa e de bolsas de

\section{FINANCING OF RESEARCH IN TROPICAL DISEASES IN BRAZIL}

The first manifestations of official support to medical research in Brazil occurred at the end of the last century, when various communicable diseases plagued the southeastern region of the country, with deleterious effects on the economy and the administration of the young republic. At that time in São Paulo, the Instituto Butantan and de Instituto Bacteriológico (later transformed into the Instituto Adolfo Lutz) were created and, in Rio de Janeiro, the Instituto Soroterápico de Manguinhos, later denominated Instituto Oswaldo Cruz in homage to its prominent founder.

These Institutes gave support to control measures against the epidemics of yellow fever, smallpox and plague, but also, particularly in the case of Manguinhos, projected the name of Brazil into the international scientific scene.

At the beginning of the second decade of this century, with the death or retirement of their leaders, these Institutes started to have difficulties in obtaining the necessary government support to give continuity to their research activities, which were eventually overwhelmed by routine work.

After the creation of the Universidade do Brasil in Rio de Janeiro, in 1922, and particularly after the foundation of the Universidade de São Paulo in 1934, new medical schools were established in other important cities. A new phase of research in Tropical Medicine began, in the wards of University Hospitals and in the laboratories of biomedical sciences. However this was not a systematic activity but rather an individual effort of some scientists who encountered many difficulties and depended too often on grants from foreign foundations.

It was only in the early fifties that the Brazilian government began to support research with the creation, in 1951, of the Conselho Nacional de Pesquisas CNPq, and of CAPES, an institution devoted to upgrading the qualifications of university teaching personnel. As a consequence, Brazilian scientists began to depend upon these governmental financing agencies to obtain research grants and scholarships. Since the beginning in both these agencies, the area of biomedical research was one of the most benefited and, 
estudo. Nesses órgãos, desde o seu início, a área de pesquisa biomédica foi das mais beneficiadas, e dentro dela, as doenças tropicais, tanto no que diz respeito à investigação fundamental quanto aos estudos clínicos.

Subseqüentemente foram também criados organismos estaduais de apoio à pesquisa como a FAPESP em S. Paulo (1961) e a FAPERGS no Rio Grande do Sul (1964), que também começaram a apoiar a pesquisa biomédica.

As grandes mudanças favoráveis todavia vieram a ocorrer na década dos sessenta quando o Governo Federal criou o Fundo para o Desenvolvimento Tecnológico - FUNTEC - no Banco Nacional de Desenvolvimento Econômico - BNDE, mais tarde substituído pelo Fundo Nacional de Desenvolvimento Cientifico e Tecnológico - FNDCT, cuja Secretaria Executiva veio a ser a Financiadora de Estudos e Projetos - FINEP.

Foi da articulação entre o CNPq, o FUNTEC/ BNDE e o FNDCT/FINEP, promovida pela Academia Brasileira de Ciências, que veio a ser criado em 1973 um Plano Integrado de Pesquisas em Esquistossomose e Doença de Chagas. Este plano começou a ser implementado em 1974, com recursos do FNDCT, repassados pela FINEP aoCNPq, que ficou incumbido da sua gestão, com a assessoria de um Grupo de Coordenação composto de renomados cientistas. A partir de 1976 o plano passou a abranger também a Leishmaniose e a Malária, e foi denominado de Programa Integrado de Doencas Endêmicas $P I D E$, como é conhecido até o presente quando já completou 10 anos de existência. Neste periodo o PIDE já aplicou recursos ca ordem de 80 milhões de dólares.

Desde o inicio da implementação do PIDE houve um esforço por parte do $\mathrm{CNPq}$ em articular a comunidade cientifica com os órgãos do Governo responsávcis pelo controle das doenças endêmicas no Brasil. Essa articulação de ínício foi muito promissora, depois atravessou uma fase de declínio, talvez mesmo de algum antagonismo, e felizmente, nos últimos quatro anos tem sido das mais frutiferas. Desde 1982 as linhas prioritárias de pesquisa do PIDE vêm sendo definidas após discussões e entendimentos entre os pesquisadores do Grupo de Coordenação do Programa, e os técnicos da Superintendência de Campanhas de Saúde Pública - SUCAM.

Os resultados obtidos ao longo dessa década de apoio contínuo à pesquisa em doenças endêmicas destacam-se sobretudo nos seguintes aspectos: within it, tropical diseases, including basic research and clinical investigation.

Later on state foundations to finance research in São Paulo (FAPESP in 1961) and in Rio Grande do Sul (FAPERGS in 1964) were founded which also supported biomedical investigation.

The most significant change however ocurred in the sixties, when the Federal Government created a fund to finance technological development (FUNTEC) at the Banco Nacional de Desenvolvimento Econômico (BNDE). Later on, its substitute, the National Fund for Scientific and Technological Development FNDCT, and its executive secretariat, the FINEP (Financiadora de Estudos e Projetos), came into being.

These organizations together with $\mathrm{CNPq}$ and the Academia Nacional de Ciências created, in 1973, an "Integrated Plan of Research in Schistosomiasis and Chagas'Disease". The implementation of this plan began in 1974 with FNDCT funds transferred by FINEP to the CNPq, that was charged with its administration, under the advice of a Coordinating Group formed by renowned scientists. After 1976, the plan was extended to include research projects in Leishmaniasis and Malaria. It was then denominated Programa Integrado de Doencas Endêmicas - PIDE (Integrated Endemic Diseases Program) which has now been in existence for 10 years. During this period the Program has invested more than $\mathbf{8 0}$ million dollars in research.

Since the beginning of the implementation of PIDE, CNPq attempted to collaborate with scientists in governmental agencies responsible for the control of endemic diseases in Brazil. This collaboration was very promising in the beginning, but later went through a phase of decline and even of some antagonism. Fortunately, in the last four years, collaboration has been very fruitful. Since 1982 , the research priorities within PIDE are only selected after lengthy discussions among scientists from the Program's Coordinating Group and the experts from the SUCAM (the Ministry of Health agency in charge of endemic disease control).

Of the results obtained after a decade of continuous support to research in endemic diseases, the following aspects deserve special mention: 


\section{a) Formação de Recursos Humanos:}

O PIDE tem apoiado, através do financiamento da pesquisa, 7 cursos de Doutorado e 18 cursos de Mestrado na área de Doenças Tropicais além de 11 outros cursos em ciências biomédicas que desenvolvem linhas de pesquisa relacionadas às doenças endêmicas, do que resultou a formação de um expressivo contingente de jovens pesquisadores nessa área. Convem, todavia, destacar como um dos fatos mais notaveis, o surgimento de uma capacitação cientifica brasileira de alto nível, de reconhecimento internacional, passando a ser comum que experts brasileiros passassem a ser regularmente convidados a compor os comitês de peritos da Organização Mundial da Saúde e de outras organizações similares.

\section{b) Desenvolvimento de Pesquisa Fundamental}

Foi da maior importância o impacto do PIDE no desenvolvimento e modernização de certas áreas das ciências biomédicas, particularmente da Bioquimica, da Imunologia, da Parasitologia e da Biologia Celular. A decisão de utilizar parasitas, particularmente o Trypanosoma cruzi, como modelo experimental, teve uma grande repercussão no desenvolvimento da Biologia Molecular no Brasil.

\section{c) Desenvolvimento de Pesquisas Clínico-Epide- miológicas}

Foi exatamente nesta área que o PIDE produziu seus resultados mais expressivos os quais vêm sendo de grande utilidade para os serviços de saúde pública, tanto federais como estaduais, no planejamento e acompanhamento das atividades de controle das grandes endemias. Merecem destaque especial o inquérito sorológico de âmbito nacional para estudo da prevalência da infecção chagásica já concluido, e a avaliação do Programa de Controle de Esquistossomose PECE, do Ministério da Saúde, ora em curso.

\section{d) Publicações Cientificas}

A produção cientifica brasileira, publicada em revistas nacionais indexadas e em revistas estrangeiras, sofreu nesses últimos 10 anos um aumento exponencial e tende a aumentar. Mais recentemente assiste-se à consolidação de mais uma publicação nacional expressiva na área, que é a Revista da Sociedade Brasileira de Medicina Tropical em sua nova fase.

\section{a) Training of Human Resources}

The Program has supported, by financing research projects, 18 Master's and 7 Doctoral Courses in the field of Tropical Diseases, in addition to 11 other graduate courses in biomedical sciences that are engaged in research related to endemic disease. This support resulted in the training of young specialists and new research workers for this area.

It is necessary however to point out, as a most significant accomplishment, a rise of Brazilian high level scientific competence in Tropical Medicine. This is internationally acknowledged. It is now commonplace to have Brazilian scientists regularly invited to be members of expert committees by the World Health Organization and similar agencies.

\section{b) Development of fundamental research}

The influence of PIDE was of the greatest importance for the development and modernization of certain fields of biomedical sciences, particularly of Biochemistry, Immunology, Parasitology and Cellular Biology. The decision to use parasites, mainly Trypanosoma cruzi, as an experimental model, had a great effect upon the development of Molecular Biology in Brazil.

\section{c) Development of clinical and epidemiological investigations}

It was specifically in this area that PIDE produced its most expressive results. These have been of great use for federal and state public health services, in planning and evaluating endemic disease control measures. Two contributions deserve special emphasis: the already concluded nationwide serologic survey to detect the prevalence of Chagas' disease, and the evaluation of the Schistosomiasis Control Program (PECE) of the Ministry of Health, which is still in progress.

\section{d) Scientific publications}

In the last ten years, the publication of Brazilian scientific papers in indexed national or international journals, experienced an exponential growth and still tends to increase. More recently took place the consolidation of another expressive Brazilian journal in the 
Apesar de todos esses êxitos, talvez em decorrência da crise financeira e da inflação, o PIDE vem sofrendo nos últimos 4 anos uma sensível redução no valor real dos auxilios concedidos. Por outro' lado, foram interrompidos os repasses do FNDCT para o CNPq, ficando o Programa restrito desde 1982 aos recursos orçamentários do CNPq.

No momento em que se cogita de obter o financiamento para mais uma fase do Programa, o PIDE VI, para o biênio 1985-1986, bem como de se introduzir modificaçōes na gestão do Programa, é indispensável uma ação política da comunidade científica da área, sob a liderança da Sociedade Brasileira de Medicina Tropical, junto às agências financiadoras, no sentido de assegurar a continuidade do PIDE, a reabertura para o Programa do acesso aos recursos do FNDCT, e, sobretudo, que a direção científica do PIDE continue sob a responsabilidade dos pesquisadores representados pelo Grupo de Coordenação do Programa.

É conveniente também, neste momento de crise, pensar de uma maneira mais abrangente, e trabalhar de forma articulada levando em conta as outras fontes de financiamento que também apóiam pesquisas em ciências biomédicas ou em Saude Pública, como as Fundações Estaduais de Amparo à Pesquisa, o Fundo de Incentivo à Pesquisa do Banco do Brasil-FIPEC, a Central de Medicamentos, CEME e o próprio Banco de Desenvolvimento Econômico e Social, BNDES. Não podem também ser esquecidas as fontes de financiamento internacional como o National Institutes of Health e a National Academy of Sciences nos Estados Unidos, e particularmente, o Programa Especial de Pesquisa e Formação de Recursos HumanosSpecial Programme for Research and Training in Tropical Diseases, da Organização Mundial de Saude (TDR/WHO), mas que poderá ampliar este apoio se houver uma ação mais coordenada por parte dos pesquisadores brasileiros.

Dentro dessa linha de um trabalho articulado merece destaque a assinatura em abril de 1984 de um Convênio entre o CNPq, a SUCAM e a Fundação Oswaldo Cruz - FIOCRUZ, do Ministério da Saúde, com o objetivo de desenvolver ações conjuntas visando a realização de pesquisas de campo e a capacitação de recursos humanos voltados para o controle das doenças endèmicas.

Dentro desse Convênio, está constituida uma Comissão Técnica composta de representantes dos órgãos convenentes e de membros da comunidade científica, a qual, desde sua instalação, vem envidando field: the Revista da Sociedade Brasileira de Medicina Tropical, in its new phase.

Despite this success, perhaps as a result of the financial crisis and inflation the program has suffered in the past 4 years a considerable reduction in the value of its grants. Also the transfer of funds from FNDCT to CNPq was discontinued, and since 1982 the PIDE has depended solely on the budget of CNPq.

At the present moment, when funds are being sought to finance a new phase of the Program for the years 1985-1986 (PIDE VI) changes in the administration of the Program are being considered. Political action from the interested scientific community, under the leadership of the Sociedade Brasileira de Medicina Tropical, is necessary to persuade the financing agencies to assure the continuity of the Program, its access to the FNDCT funds and the maintenance of scientific leadership in the conduction of PIDE.

At this moment of crisis it is also convenient, to work in a more articulated way and take into account all sources of financing that support research in biomedical sciences and in Public Health, such as the State Foundations (FAPESP, FAPERGS), the fund for research support of the Bank of Brazil (FIPEC), the federal medicaments supply central (CEME), and even the National Bank for Economic and Social Development (BNDES). We must not forget sources of financial support from international agencies, such as the National Institutes of Health, and the National Academy of Sciences in the United States, and, particularly, the Special Program for Research and Training of Human Resources in Tropical Diseases of the World Health Organization (TDR/WHO), already support a significant number of research projects in Brazil, and could increase this support if there were more coordinated action among Brazilian scientists and administrators.

Relevant to such articulated action was the signature, in April 1984, of an agreement between CNPq, and SUCAM and the Oswaldo Cruz Foundatio - FIOCRUZ, of the Ministry of Health, with the object of supporting joint actions leading to further development of field research and training of personnel concerned with the control of endemic diseases.

As part of this agreement a Technical Committee was constituted composed of representatives of the convening agencies and of scientists. Since its creation 
Editoriais. O financiamento da pesquisa em doenças tropicais no Brasil, José Duarte de Araújo, e Haemagogus leucocelaenus em ambiente urbano, Pedro Luiz Tauil. Revista da Sociedade Brasileira de Medicina Tropical 18: 1-5, Jan-Mar, 1985

esforços no sentido de uma definição clara das prioridades para pesquisa, da busca de um melhor entrosamento entre os pesquisadores e os usuários da pesquisa - os órgãos de controle - e, particularmente, de facilitår o acesso do pesquisador na área de doenças tropicais ao conjunto das fontes de financiamento existentes dentro ou fora do pais. it has been working to obtain a clear definition of research priorities. It is also seeking a better understanding and cooperation between the scientists and the users of research - the disease control agencies and, particularly, to facilitate the access of scientists from the field of Tropical Diseases to the financing agencies both in Brazil and abroad.

\section{HAEMAGOGUS LEUCOCELAENUS EM AMBIENTE URBANO}

Por ocasião do XXI Congresso da Sociedade Brasileira de Medicina Tropical, recentemente realizado em São Paulo, foi apresentado, como tema livre, um trabalho intitulado "Haemagogus leucocelaenus em área urbana de municípios do interior do Estado de São Paulo", de autoria de Moretti L A, Martins M M, Magro L G e Amaral A L M, da Superintendência de Campanhas de Saúde Pública - SUCAM Diretoria Regional de São Paulo.

Os autores descreveram a descoberta de larvas do mosquito acima referido, nas sedes dos municipios de Turmalina e Populina, nos meses de março e abril de 1984, durante as atividades de rotina de vigilância do Aedes aegypti naquele Estado.

É nossa intenção ressaltar a importância desse fato, repetido em outras cidades do Brasil, como Fortaleza, e em cidades de outros paises da América, como no Equador.

Tratando-se de espécie de mosquito primitivamente silvestre e encontrado na copa das árvores, susceptivel ao virus da febre amarela, torna-se muito importante, como salientaram os autores do trabalho, uma continuidade das investigações entomológicas, bem como outros estudos sobre a susceptibilidade das cepas, encontradas em ambiente urbano, ao vírus da febre amarela, a fim de poder-se avaliar o risco de transmissão urbana da doença por esses mosquitos.

É do nosso conhecimento que a SUCAM está promovendo gestões junto ao Instituto Evandro Chagas, da Fundação SESP, do Ministério da Saúde, no sentido de promover estudos sobre a susceptibilidade das cepas de $\mathrm{Hg}$. leucocelaenus encontradas em área urbana.

\section{HAEMAGOGUS LEUCOCELAENUS IN AN URBAN ENVIRONMENT}

At the XXI Congresso da Sociedade Brasileira de Medicina Tropical held recently in São Paulo, a free communication was presented entitled "Haemagogus leucocelaenus in urban areas of municipalities in the interior of São Paulo State" by Moretti L A, Martins $\mathbf{M}$ M, Magro L $\mathbf{G}$ and Amaral A L M, from the Superintendência de Campanhas de Saúde Pública SUCAM of São Paulo.

The authors described the finding of larvae of the mosquito referred to above in houses in the municipalities of Turmalina and Populina in the months of March and April of 1984, during the routine vigilance activities for Aedes aegypti in that State.

We wish to draw attention to this important finding which has also occurred in other Brazilian cities, like Fortaleza, and in cities of other American countries such as Ecuador.

This species of mosquito is primarily sylvatic, being encountered in tree tops. It is susceptible to the virus of yellow fever. As the authors emphasise, it is very important to continue these entomological investigations. Also the susceptibility of such urban dwelling mosquitoes to yellow fever virus must be studied to evaluate the risk of urban transmission by this species.

To this aim SUCAM is collaborating with the Instituto Evandro Chagas, Fundação SESP, Ministry of Health to stimulate studies, of the susceptibility of strains of $\mathrm{Hg}$. leucocelaenus encountered in urban areas. 